\title{
RESEARCH OF HEAT AND MASS TRANSFER \\ DURING CONVECTIVE DRYING \\ OF COLLOID CAPILLARY-POROUS MATERIALS
}

\section{Kateryna Slobodianiuk ${ }^{1}$ \\ Kateryna Samoilenko}

DOI: https://doi.org/10.30525/978-9934-26-021-6-39

Abstract. The article presents a reasonable analysis and relevance of the study of the drying process of vegetable raw materials (colloidal capillaryporous materials). Drying is an energy-intensive industrial process that is defined from a technological point of view: on the one hand by heat and moisture exchange between the body surface and the environment, on the other hand by heating the body and transferring moisture inside it due to the form of moisture. One of the most effective ways to increase the shelf life of food is to dry it to equilibrium humidity. Very important are the technological parameters of the drying regimes, which, when used rationally, are able to preserve the biochemical properties and nutrients of the raw material at a high level in the obtained dry product. The study of dehydration of vegetable raw materials is widely practiced around the world, especially in countries such as Germany, France, USA, Argentina, Hungary, Brazil, Poland, Korea, China, Malaysia. However, the obtained processed products lose their biologically active components and nutrients, and the processing process is energy consuming. Therefore, the problem is relevant and needs an effective solution. In this paper, the kinetics of the drying process, thermogravimetric studies and a mathematical model for colloidal capillary-porous materials of plant origin were analyzed. According to the results of the highlighted research, the process of convective drying of colloidal capillary-porous materials was intensified above $21 \%$ due to the use of innovative step regimes. The developed beet-rhubarb composition is a colloidal capillary-porous material that stabilizes and protects at the

\footnotetext{
${ }^{1}$ Ph.D., Researcher of Department of the Heat and Mass Transfer in Heat Technologies, Institute of Engineering Thermophysics of National Academy of Sciences of Ukraine, Ukraine ${ }^{2}$ Ph.D., Senior Researcher of Department of the Heat and Mass Transfer in Heat Technologies, Institute of Engineering Thermophysics of National Academy of Sciences of Ukraine, Ukraine

(C) Kateryna Slobodianiuk, Kateryna Samoilenko
} 
biochemical level betanin of the beet from the effects of temperature during convective drying, has in comparison with the components of the composition lower heat of dehydration and increased thermal-stability. Prolonged high-temperature exposure causes instant complete destruction of sugars, proteins and other nutrients components. Derivatographic studies have confirmed that the use of the temperature range of $100^{\circ} \mathrm{C}$ in a stepwise mode of $100 / 60^{\circ} \mathrm{C}$ for the developed soybean-spinach composition is safe for biologically active substances and it is justified by experimental temperature curves. Numerical modeling of heat and mass transfer during convective drying of crushed beets and crushed soybeans using the known model by A.V. Lykov satisfactorily describes the process and can be used to model the convection drying of colloidal capillary-porous materials.

\section{Introduction}

Outdated technologies lead to irrational use and high energy consumption, increase energy consumption and import. This brings the issue of energy saving and energy efficiency to one of the most important tasks to be solved.

In modern conditions, these issues are an integral part of the problem of ecology. Ukraine, having a unique environment for Europe, being fully supplied with natural resources, is at the same time one of the countries in the region where energy resources are used the least efficiently and there are many environmental problems.

The polluted environment directly affects the physical condition of the population. Poor nutrition, constant stress, ecology - a complex that interacts daily with the human immune system. Nutrition is a key moment in the life of every living organism. Food occupies a leading place in everyone's life. The Ministry of Health of Ukraine reports: "The highest mortality rate in the world is caused by malnutrition. This Figure is higher than due to smoking, high blood pressure and other risk factors»».

Therefore, food must have functional properties, and their processing should ensure maximum preservation of biologically active substances contained in them while reducing energy consumption for processing.

\section{Relevance and existing research}

Nowadays, the international status of Ukraine depends on the effective realization of its advantages of resource potential in the world labor 
market and in competitiveness. In the agricultural sector of Ukraine, its development strategy should be aimed at creating an environmentally safe, efficient, socially oriented, resource-saving, scientific sector of the state economy that can ensure the position of world food market leader in agricultural products and meet domestic needs. Therefore, the development of energy-efficient heat technologies in the food industry is an important stage. Drying refers to energy efficient processes. From the technological point of view, the drying process is determined on the one hand by heat and moisture exchange between the body surface and the environment, on the other hand - by heating the body and transferring moisture inside it due to the form of moisture. The problem of processing, drying and use of vegetable raw materials with full preservation of its functionality is very relevant due to the wide range of its use in the food and pharmaceutical industries. When drying, the weight of the product is significantly reduced, which reduces the cost of transportation, packaging and reduces the need for storage space.

Investigation of the process of drying of plant material involved are carried out in countries such as Germany, France, USA, Argentina, Hungary, Brazil, Poland, Korea, China, Malaysia and others [1-5].

Given all this, there is a need to develop and improve thermal technologies for drying vegetable raw materials, which will process products with minimal energy consumption, long shelf life and preservation of biologically active substances.

\section{Materials and methods of researches}

In this paper, the kinetics of the drying process, thermogravimetric studies and calculated a mathematical model of drying for colloidal capillary-porous materials of plant origin were analyzed.

Our research has shown that each plant raw material requires appropriate technological modes of preparation and drying [6].

From the comparative analysis of the latest researches and publications there is a necessity of research of influence of technological parameters of processes of pre-treatment preparation and dehydration of vegetable raw materials on energy consumption at manufacturing of functional powders on the basis of objects of research. The objects of the study were colloidal capillary-porous materials, representatives of 2 functional subgroups, 
namely phytoestrogenic mixture $(1: 1)$ - soy-spinach; antioxidant mixture (2:1) - rhubarb-beet.

For this purpose, was experimental studies of the drying process of prepared raw materials at a step temperature of $100 / 60^{\circ} \mathrm{C}$ on a convective drying stand with continuous automatic collection and processing of information about changes in mass, sample temperature using the developed application program «Sooshka», which allows calculations with construction drying curves [7].

The prepared mono-raw material and compositions were poured on a mesh tray measuring $100 \times 50 \mathrm{~mm}$, which was placed on a weighing rod in the drying chamber. Thermocouples were inserted inside the material to measure the temperature change of the material during drying. Studies of the drying process were carried out to the final moisture content of the material $\mathrm{W}_{\mathrm{c}}^{\mathrm{c}}=4 \%$, because, as is known, drying materials to a moisture content below $5 \%$ can significantly increase their shelf life in powder form. To determine the current humidity of the material, the samples were dried after the experiment to absolutely dry weight at $100 \ldots 105^{\circ} \mathrm{C}$ (GOST 28561-90 «Determination of humidity by the method of drying to constant weight»).

Studies to determine the heat of dehydration and thermal stability were performed using a derivatographic method that combines thermogravimetry (TG) with classical differential thermal analysis (DTA). This method allowed to study the state of mono-substances and compositions under programmable heating [8]. Qualitative and quantitative analysis of the processes that took place during the heating of the samples at a constant rate is realized with derivatograms - a set of curves of change: temperature of the sample (T), its mass (TG), mass change rate (DTG) and DTA curve (difference of thermoelectromotive forces of thermocouples of the sample) due to which it is possible to identify thermal processes.

The studies were performed on a Q-1000 derivatograph of the PaulikPaulik-Erdey system (IOM, Hungary) [9] in the range of $25 \ldots 250^{\circ} \mathrm{C}$ at a heating rate of $3.6 \mathrm{~K} / \mathrm{min}$. Atmosphere - still air. The inert substance in the reference crucible was alumina. The temperature scale was corrected by the melting point of benzoic acid $\left(122.4^{\circ} \mathrm{C}\right)$ [10]. The temperature deviation did not exceed $\pm 0.5 \mathrm{~K}$. Using the Derivatograph computer application created in the Delphi programming environment, the obtained data were collected 
and processed. Samples before the study were ground in a meat grinder and crushed in a mortar to a single fractional state of particles. Samples were placed in an open conical platinum crucible from a set of derivatographs.

Calculations of the mathematical model of the theoretical study of heat and mass transfer on the basis of the existing and known theory of Lykov A.V., were carried out by means of DELPHI programming.

\section{Research results}

Based on the known previous studies of the authors presented in $[7 ; 11]$, the preliminary preparation of raw materials [12-13] and the use of a step temperature of $100 / 60^{\circ} \mathrm{C}$ for convective drying of colloidal capillaryporous materials of plant origin is proposed. The principle of studying the effect of gradual change of heat-coolant temperature on the drying process of colloidal capillary-porous materials is as follows: the coolant temperature is reduced from the initial 100 to $60^{\circ} \mathrm{C}$, when the temperature in the material layer approached the allowable $\left(60^{\circ} \mathrm{C}\right)$.

Drying curves of phytoestrogenic mixtures have a characteristic appearance for colloidal capillary-porous materials. As the heat-coolant temperature increases, the intensity of the drying process of the mixtures increases.

Drying curves using the developed step regime $100 / 60^{\circ} \mathrm{C}$ for phytoestrogenic soy-spinach mixture, spinach - thermolabile material, are presented in Figure 1 [7]. It is established: the use of step $\left(100 / 60{ }^{\circ} \mathrm{C}\right)$ change of heat-coolant temperature during drying of phytoestrogenic raw materials allows to reduce drying time in comparison with the monotemperature mode of $60^{\circ} \mathrm{C}$, there is an intensification of process by $21 \%$, the average speed of process is increased. Additional studies of qualitative characteristics confirmed the lack of negative impact on the biochemical components of raw materials [14].

Due to the fact that when drying plant materials, the increase in energy costs is due to the complicated permeability of cell membranes to water and the complexity of the water removal process (due to interaction with soluble components of cell juice and skeletal molecules) and due to lack of data in the literature, it is important to investigate the effect of creating functional compositions of vegetable raw materials on the value of heat consumption for dehydration of mixtures and their thermal-stability. 


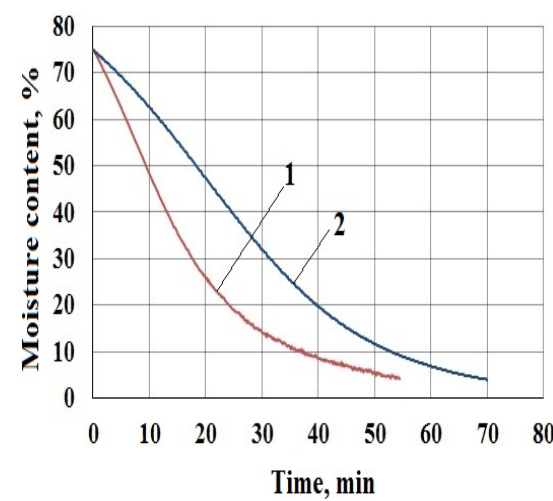

Figure 1. Change in moisture content of soybean-spinach mixture under the influence of heat-coolant temperature $60^{\circ} \mathrm{C}$ and $100 / 60^{\circ} \mathrm{C}$. Mode parameters: $\delta=15 \mathrm{~mm}, \mathrm{~W}^{\mathrm{c}} \mathrm{K}=4 \%$; $\mathrm{v}=2,5 \mathrm{~m} / \mathrm{sec}, \mathrm{d}=10 \mathrm{~g} / \mathrm{kg}$ dry air: $1-100 / 60^{\circ} \mathrm{C}, 2-60^{\circ} \mathrm{C}$

It is known from the literature that there is a significant difference between the actual values of specific heat consumption for their dehydration from the heat of evaporation of pure water [10]. The increase in energy consumption for the drying process of materials of plant origin is associated with the removal of water associated with molecules and ions of cell sap, as well as biopolymers of the skeleton of the material $[6 ; 10 ; 15]$.

The objective of the study was to determine whether the effect on heat dehydration and thermal stability of the table beet reduction of $\mathrm{pH}$ by creating a composite mixture of beet-rhubarb (the ratio of table beet to the rhubarb into the mix was the 2:1) and formation of a composite mixture of soybeans-spinach (ratio of soybeans to spinach in the mixture was as 1:1).

In Figure 2-4 presents the obtained derivatograms. The derivatives show that the change in the mass of the samples (TG curves) with simultaneous heat absorption (DTA curves) starts at $25.0^{\circ} \mathrm{C}$ and indicates the removal of water. With increasing temperature, the rate of dehydration (DTG curves) increases, reaching its maximum at a certain temperature (Table 1). At maximum points, samples of table beets, rhubarb and mixtures acquire a relative humidity $\mathrm{W}$, respectively, 30.37, 21.36 and $32.94 \%$. For table beets by differential scanning calorimetry, it was shown [16] that the maximum moisture content, after which only bound water remains in the tissues, corresponds to a relative humidity of $26.0 \%$ (Figure 2). That is, the temperature of the maximum rate of dehydration (DTG) or heat absorption (DTA) does not divide water into free and bound, as suggested in some studies. 


\section{Chapter «Engineering sciences»}

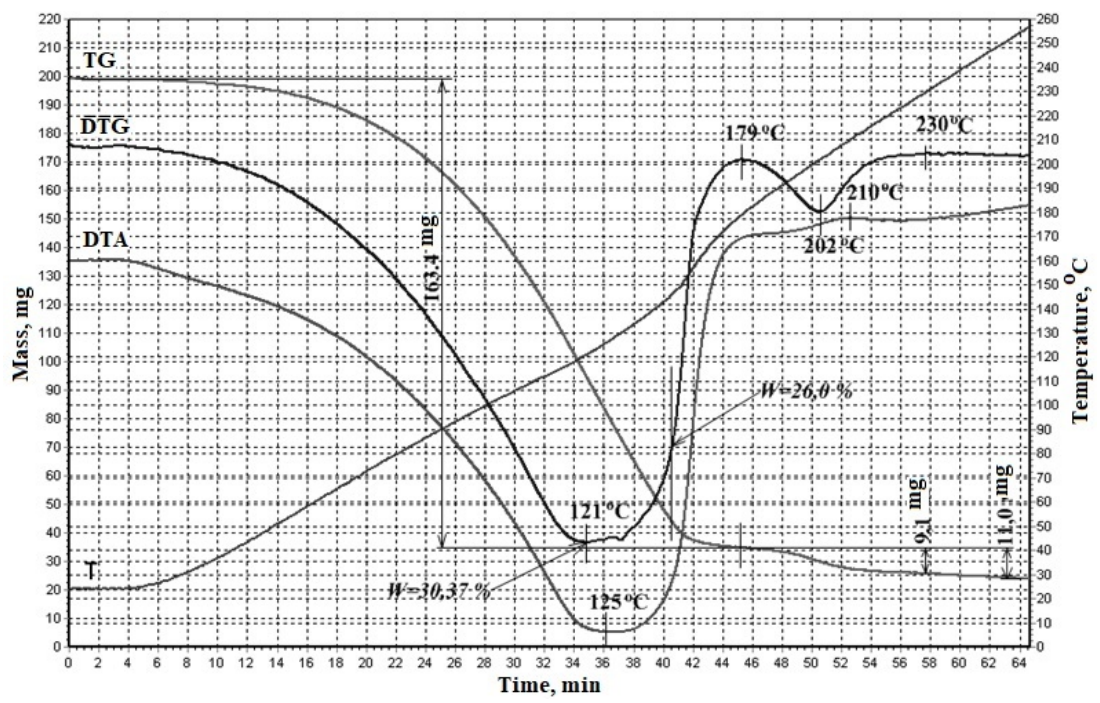

Figure 2. Derivatogram of of table beets. Sample weight $198.2 \mathrm{mg}$

After reaching the maximum, the rate of dehydration drops to zero, which corresponds to complete dehydration of the samples. The temperature of complete dehydration for the studied raw materials is practically the same and is at the level of $178-179^{\circ} \mathrm{C}$ (table 1). However, the rate of dehydration depends on the nature of the material. Beetroot has the lowest speed and rhubarb has the highest speed. A mixture of beets with rhubarb has a higher rate of dehydration than beets. This fact is most likely due to the difference in humidity of the samples. The higher the initial humidity, the higher the average rate of dehydration (table 1).

In the gravimetric study of table beets after complete dehydration in the range of $179-230^{\circ} \mathrm{C}$, the loss of mass (TG) of the sample with the maximum peak velocity (DTG) at $202^{\circ} \mathrm{C}$ is registered (Figure 2). Moreover, this change in mass occurs with the release of heat, the maximum of which is at $210^{\circ} \mathrm{C}$ (DTA). According to the characteristic features, this process refers to thermal decomposition, but from this study it is not possible to establish a degrading substance. On the derivatograms of rhubarb and a mixture of beets with rhubarb in the studied temperature range of thermal 


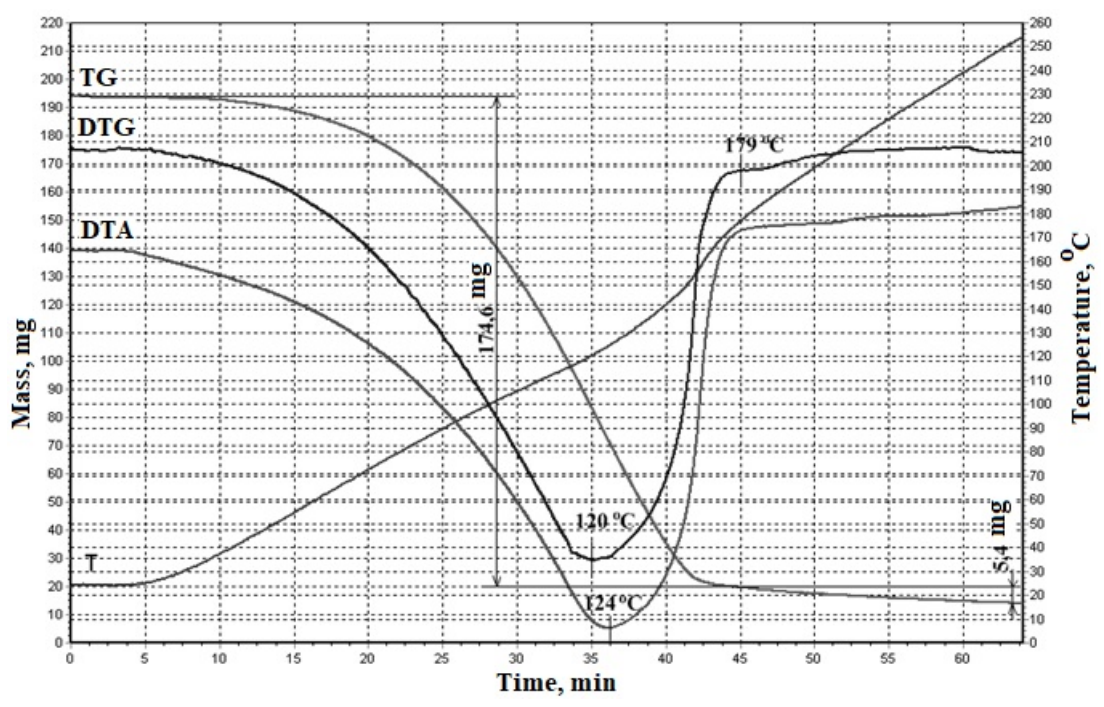

\section{Figure 3. Derivatogram of a mixture of table beet with rhubarb in a ratio of $2: 1$. Sample weight $194.0 \mathrm{mg}$}

decomposition processes with a sharp change in mass was not detected (Figure 3). However, after complete dehydration, there is a slow decrease in sample weight (TG). The table shows that the rate of thermal destruction is highest in beets, and lowest - in the mixture.

The difference in the values of the temperatures of the maxima $\Delta \mathrm{T}$ of the dehydration rate and thermal decomposition recorded on the DTG and DTA curves is related to the influence of the thermal conductivity of the samples on the electromotive force of the measuring thermocouple. The lower the thermal conductivity, the greater the temperature difference. For wet samples $\Delta \mathrm{T}=2-4^{\circ} \mathrm{C}$ (Figure 2-4) for dry material $\Delta \mathrm{T}=8^{\circ} \mathrm{C}$.

Using the method described in [16], the heat expended on dehydration during the derivatographic study was estimated (Table 1). From the table we see that most of the heat is expended during dehydration of table beets, as raw materials with a high content of bound water [10]. The heat consumption for rhubarb dehydration is slightly lower. However, the specific heat consumption during dehydration of a mixture of table beets 


\section{Chapter «Engineering sciences»}

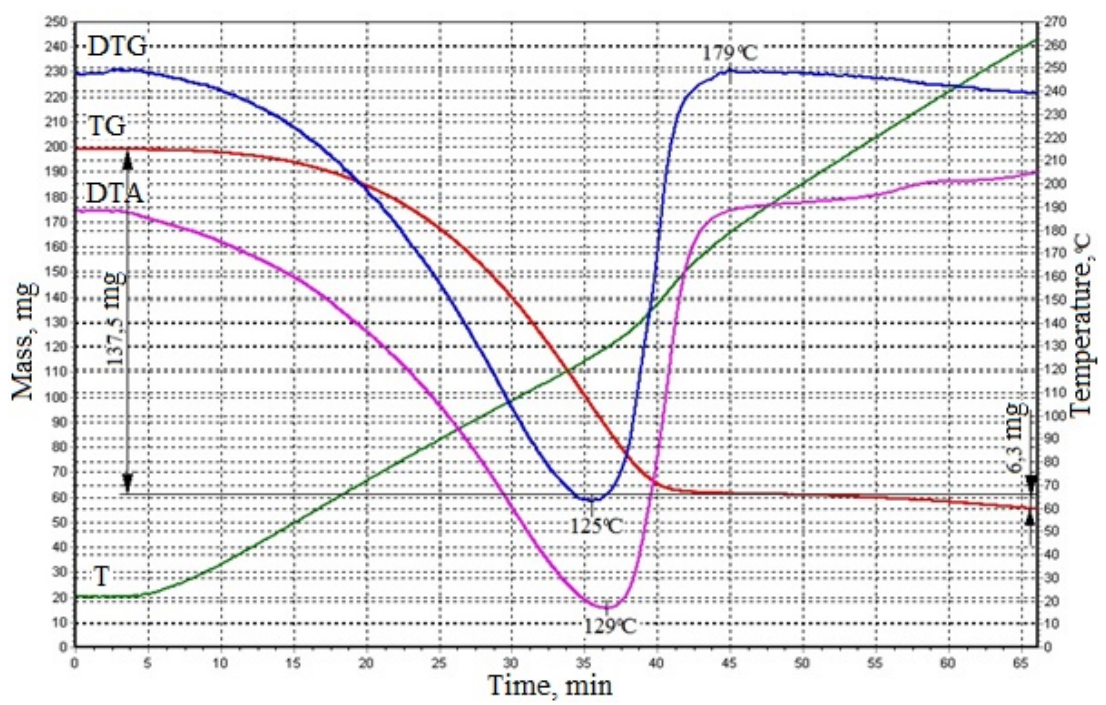

Figure 4. Derivatogram of soy-spinach mixture (1:1). Sample weight $199 \mathrm{mg}$

with rhubarb is much smaller than the cost of dehydration of individual components of the mixture. The most likely reason for this decrease in heat consumption is a significant reduction in the content of bound water in the mixture, which may be due to changes in the structure and composition of the components of the mixture under conditions of low $\mathrm{pH}$.

After analyzing the obtained graphs for derivatographic on a mixture of soybeans and spinach (Figure 4), we can state that the removal of water, as evidenced by the change in mass of objects (TG curves), with simultaneous heat absorption (DTA curves) begins with $22-24.0^{\circ} \mathrm{C}$ (table 1). After passing the maximum points, the tested samples of mono-raw materials and mixtures reach their values of the maximum moisture content, at this stage only bound water remains. It is known that the temperature of the maximum rate of water removal (DTG) or heat absorption (DTA) in the range of $22-196^{\circ} \mathrm{C}$ does not separate water into free and bound [16]. The rate of water removal after the peak peaks to zero and this means - complete dehydration of the samples. Depending on the structure of the material and 
its chemical composition will be the appropriate rate of removal of water from it. From previous studies [15] it is known that the highest value in spinach, the lowest - pre-hydrothermally treated soybeans.

Table 1

The results of the analysis of derivatographic curves of antioxidant and phytoestrogenic raw materials

\begin{tabular}{|c|c|c|c|c|c|c|c|c|}
\hline \multirow[b]{2}{*}{ Material } & \multirow[b]{2}{*}{ 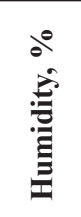 } & \multicolumn{4}{|c|}{ Water removal } & \multicolumn{3}{|c|}{ Thermal destruction } \\
\hline & & 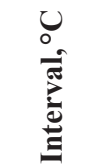 & 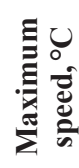 & 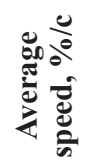 & $\underbrace{+\infty}$ & 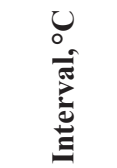 & 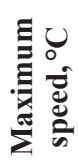 & 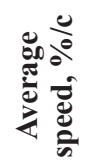 \\
\hline $\begin{array}{l}\text { beet-rhubarb } \\
\text { mixture }\end{array}$ & 90,00 & $25-179$ & 120 & 0,033 & 2276 & $179-254$ & - & 0,025 \\
\hline $\begin{array}{c}\text { soybean - } \\
\text { spinach mixture }\end{array}$ & 69,09 & $22-179$ & 125 & 0,027 & 2545,4 & $179-240$ & - & 0,026 \\
\hline
\end{tabular}

After dehydration, there is a moderate decrease in sample weight (TG). After overcoming the temperature barrier of $100-105^{\circ} \mathrm{C}$ in the soy-spinach mixture, there is an instant complete destruction of sugars, proteins and nutrients contained in protein-containing phytoestrogenic mixtures. The difference in the values of $\Delta \mathrm{T}$ temperatures of the maximums of water removal rate and thermal destruction (combustion), showing the curves of DTG and DTA, is associated with the influence of thermal conductivity of vegetable raw materials (samples) on the EMF of the measuring thermocouple $[10 ; 15]$.

According to the method described in [17], the heat expended on dehydration of the samples was estimated (Table 1). The specific heat consumption during dehydration of mixtures of carotene-containing components with soybeans is much lower than the cost of dehydration of mono-components of the mixture [15].

It should be noted that the specific heat of dehydration is determined in non-isothermal conditions and its values should be considered as the average obtained in the temperature range $25-179{ }^{\circ} \mathrm{C}$.

The ratio of the specific heat of dehydration of beets, rhubarb and their mixtures; soybeans, spinach and their mixtures correlate with the results 
obtained by studying the specific heat of evaporation of water from these materials in a differential microcalorimeter of evaporation [17].

In addition to experimental studies of colloidal capillary-porous materials, numerical modeling of the heat and mass transfer process during the drying of phytoestrogenic raw materials was performed [15; 18]. Numerical modeling of the process of convection drying of colloidal capillary-porous material (vegetable raw materials) is performed on the basis of the finite-difference solution of the system of heat and mass transfer equations, which consists of:

- mass transfer equation: $\frac{\partial u}{\partial \tau}=K_{11} \nabla^{2} u+K_{12} \nabla^{2} T$

- heat transfer equation: $\frac{\partial T}{\partial \tau}=K_{21} \nabla^{2} u+K_{22} \nabla^{2} T$

where $u, \mathrm{~kg} / \mathrm{m}^{3}$ - specific moisture content of the material; $T, K-$ temperature; $\tau$, sec - time, $\nabla^{2}$ - Laplace operator.

The coefficients included in the given system of equations have the form:

$$
K_{11}=a_{m} ; K_{12}=a_{m}^{T} ; K_{21}=\frac{r \varepsilon a_{m}}{C_{p} \rho} ; K_{22}=\frac{\lambda}{C_{p} \rho}+\frac{r \varepsilon a_{m}^{T}}{C_{p} \rho},
$$

where $a_{m}, \mathrm{~m}^{2} / \mathrm{sec}$ - moisture diffusion coefficient in colloidal capillaryporous material; $a_{m}^{T}, \mathrm{~kg} /(\mathrm{m} \cdot \mathrm{K} \cdot \mathrm{sec})$ - moisture thermal diffusion coefficient; $\rho, \mathrm{kg} / \mathrm{m}^{3}$ - effective material density; $\lambda$ - effective thermal conductivity of the material;

$C_{p}, \mathrm{~J} /(\mathrm{kg} \mathrm{K})$ - effective heat capacity of the material; $r, \mathrm{~J} / \mathrm{kg}$ - specific heat of moisture evaporation; $\varepsilon(0<\varepsilon<1)$ - phase transformation coefficient, which determines the proportion of water vapor flow relative to the total flow of liquid and vapor moisture.

For numerical modeling of the convection drying process, a sample of rectangular soybean raw material with a thickness of $\delta$, placed in the drying chamber. The surfaces of the sample are washed with a coolant, ie dry heated air having a temperature $T_{\infty}$ and the relative concentration of water vapor $\rho_{v, B, \infty}$. (Figure 5). The air flow rate in the drying chamber moving in the longitudinal direction has a value $v_{\infty}$. The relative concentration of water vapor is defined as the ratio of the partial density of water vapor to the density of the vapor-air mixture. 
The physical model of the drying process involves the transfer of heat by convection from the heated air stream to the surface of the layer of material to be dried. The water vapor formed as a result of drying the material is removed into the coolant stream. The main transfer of heat and moisture occurs in the direction perpendicular to the surface of the material.

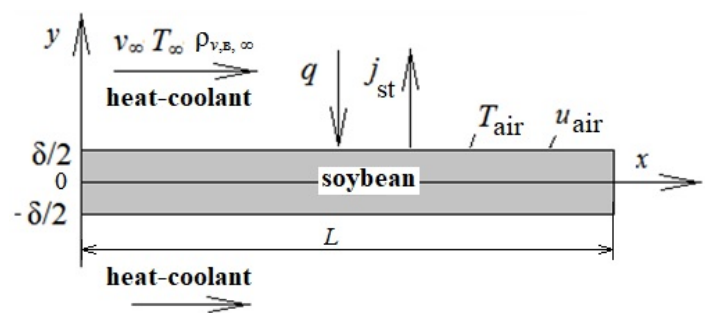

Figure 5. Scheme to the physical model of the convection drying process

In the case of a small sample thickness $\delta$ heat and mass flows in the longitudinal direction can be neglected. In this case, the problem of heat and mass transfer is considered in an approximate one-dimensional formulation. If the temperature gradients in the thickness of the material are relatively low, you can also ignore the transfer of moisture by thermal diffusion. In this case $K_{12}=0 ; K_{22}=\frac{\lambda}{C_{p} \rho}$. Under these conditions, equations (4) and (5) are simplified and take the form:

$$
\begin{gathered}
\frac{\partial u}{\partial \tau}=a_{m} \frac{\partial^{2} u}{\partial y^{2}} \\
\frac{\partial T}{\partial \tau}=a_{T} \frac{\partial^{2} T}{\partial y^{2}}+\frac{r \varepsilon}{C_{p} \rho} \frac{\partial u}{\partial \tau}
\end{gathered}
$$

where $a_{T}=K_{22}=\frac{\lambda}{C_{p} \rho}$ - effective coefficient of thermal conductivity of colloidal capillary-porous material.

The initial conditions for nonstationary equations (6) and (7) are temperature distributions $\mathrm{T}$ and specific moisture content $\mathrm{u}$ on the thickness of the material at $\tau=0$. Speed is also a known quantity, temperature $T_{\infty}$ and the relative humidity of the heat-coolant $\varphi_{\infty}$. To formulate the boundary 
conditions, it is assumed that the heat and mass transfer process proceeds symmetrically about the axis $0 \mathrm{X}$. In this case, the system of equations (6), (7) is considered only in the domain $0 \leq y \leq \delta / 2$ (Figure 6), and at $y=0$ the conditions of symmetry in the form are set:

$$
\left.\frac{\partial u}{\partial y}\right|_{y=0}=0 ;\left.\frac{\partial T}{\partial y}\right|_{y=0}=0 .
$$

On the surface of the sample to be dried, the boundary conditions must determine the balance of moisture removed from the material and entering the coolant, as well as the balance of heat coming from the coolant to the material and spent on heating the material and evaporating moisture from the surface. The total flow of liquid and vapor moisture coming from the middle of the material to its surface is defined as $j_{\sigma_{e}}=-\left.a_{m} \frac{\partial u}{\partial y}\right|_{y={ }^{\prime} / 2}$. From the surface of the material to the coolant, moisture is transferred in the form of vapor by diffusion. The density of this flow is calculated by expression $j_{\varepsilon}=-\left.D_{v a} \rho_{a} \frac{\partial \rho_{v, 2}}{\partial y}\right|_{y=\delta / 2}$, where $D_{v a}-$ water vapor diffusion coefficient in air. Therefore, the boundary condition to equation (6) on the heat and mass transfer surface has the form:

$$
-\left.a_{m} \frac{\partial u}{\partial y}\right|_{y=\delta / 2}=-\left.D_{v a} \rho_{a} \frac{\partial \rho_{v, 2}}{\partial y}\right|_{y=\delta / 2}
$$

The heat flux flowing to the surface of the material from the coolant is equal to $q_{a}=-\left.\lambda_{a} \frac{\partial T}{\partial y}\right|_{y=\delta / 2}$, where $\lambda_{a}$ - coefficient of thermal conductivity of air. The heat flux density transferred from the heat and mass transfer surface into the material is calculated as $q_{m}=-\left.\lambda \frac{\partial T}{\partial y}\right|_{y=\delta / 2}$. The heat flux density expended on the evaporation of moisture from the surface is proportional to the flux density of the liquid moisture, ie, $q_{e v}=-r\left(1-\varepsilon_{a i r}\right) a_{m} \frac{d u}{d y} y=\delta 2$.

Expression $\left(1-\varepsilon_{\text {air }}\right)$ determines the proportion of the flow of liquid moisture from the total flow of moisture coming on the heat and mass transfer surface has the form: 


$$
-\left.\lambda \frac{\partial T}{\partial y}\right|_{x=\delta / 2}=-\left.r\left(1-\varepsilon_{a i r}\right) a_{m} \frac{\partial u}{\partial y}\right|_{x=\delta / 2}=-\left.\lambda_{a} \frac{\partial T}{\partial y}\right|_{x=\delta / 2},
$$

To calculate the heat flux density and water vapor flux density on the surface of the material from the coolant, the expressions are used:

$$
\begin{gathered}
-\left.D_{v a} \rho_{a} \frac{\partial \rho_{v, 2}}{\partial y}\right|_{y=\delta / 2}=\beta\left(\rho_{v, 2, \text { air }}-\rho_{v, 2, \infty}\right) \\
-\left.\lambda_{a} \frac{\partial T}{\partial y}\right|_{x=\delta / 2}=\alpha\left(T_{\text {air }}-T_{\infty}\right),
\end{gathered}
$$

where $\alpha, \mathrm{W} /\left(\mathrm{m}^{2} \mathrm{~K}\right)$ - heat transfer coefficient; $\beta, \mathrm{kg} /\left(\mathrm{m}^{2} \mathrm{sec}\right)-$ mass transfer coefficient, Tair - surface temperature of heat and mass transfer, $\rho_{v, 2, \text { air }}$ - the relative concentration of water vapor in the coolant near the surface of the material.

A rectangular sample of CCPM in length is considered $L_{1}=100 \mathrm{~mm}$; width $L_{2}=50 \mathrm{~mm}$ and thickness $\delta=15 \mathrm{~mm}$. The temperature of the heatcoolant (heated air) at the entrance to the drying chamber is $t_{\infty}=60^{\circ} \mathrm{C}$, and its relative humidity $\varphi_{\infty}=7 \%$. Under these conditions $\rho_{v, b, \infty}=0,00858$. Air flow rate in the drying chamber $u_{\infty}=2,5 \mathrm{~m} / \mathrm{sec}$. The initial mass of the sample is $m_{\mathrm{n}}=33,78 \mathrm{~g}$. Mass of dry material (after complete removal of moisture) $m_{\mathrm{c}}=12,79 \mathrm{~g}$. The initial temperature of the soybean layer varies linearly from $37,1^{\circ} \mathrm{C}$ in the middle of the sample $(y=0)$ to $46,7^{\circ} \mathrm{C}$ on its surface $(y=\delta / 2)$. The initial specific moisture content is $u_{0}=280,0 \mathrm{~kg} / \mathrm{M}^{3}$. Sorptiondesorption curves for determining the equilibrium moisture content of crushed soybeans depending on the relative humidity and thermophysical properties of crushed soybeans are taken from scientific publications.

The results of numerical simulation of the temperature regime of the drying process were compared with experimental data. Figure 7 shows the change in temperature over time in the middle of this soybean sample. Curve (1) corresponds to the results of numerical simulation, and curve (2) - the results of the experiment. As can be seen from Figure 6 in the middle of the sample, the temperature varies rapidly for 120 minutes from the beginning of the drying process.

An important integral characteristic of the drying process is the time dependence of the mass of the sample to be dried. In Figure 7 (curve 1) 


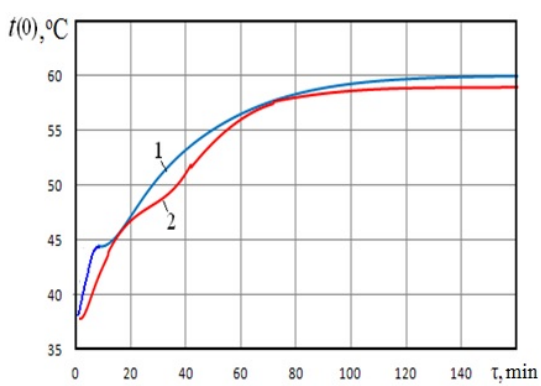

Figure 6. Time change of temperature inside of the soybean layer during its drying:

1 - results of numerical simulation; 2 - experimental data

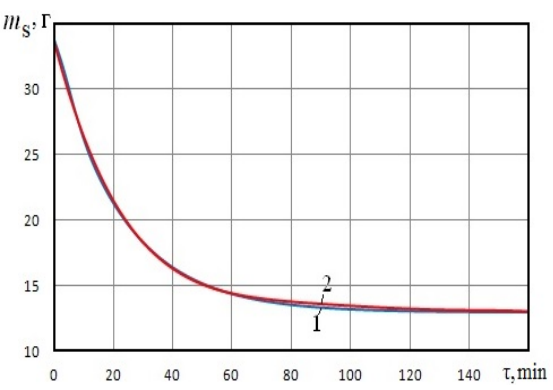

Figure 7. Time change of the mass of the soybean layer during its drying:

\section{1 - results of numerical simulation;}

2 - experimental data

shows the results of calculating the change in time of the mass of the soybean sample during its drying.

As can be seen from Figure 7, for the first 80 minutes from the beginning of the drying process, the mass of the soybean sample due to moisture evaporation decreases from the initial value of $33.78 \mathrm{~g}$ to $13.5 \mathrm{~g}$. Then the process of removing moisture is significantly slowed down.

Comparison of the results of numerical simulations with the calculation data indicates their satisfactory agreement.

Another important integral characteristic of the drying process is the change over time in the relative concentration of moisture in the material $w(\tau)$. This value is calculated by the formula:

$$
w=\frac{m_{3}-m_{c}}{m_{3}} \cdot 100 \%
$$

Its dependence on time is shown in Figure 8. The nature of the change in this value is generally similar to the change in the $m_{3}$ value. For the first 60 minutes from the beginning of drying the value $w(\tau)$ varies quite intensively: from $62 \%$ to $11 \%$. In the future, its change in time slows down. This value is also determined from the experiment.

As can be seen from Figure 8, on the time interval $0<\tau<60 \mathrm{~min}$. the calculated results and experimental data agree quite well. Then, at the stage of drying, there is a slight discrepancy. 


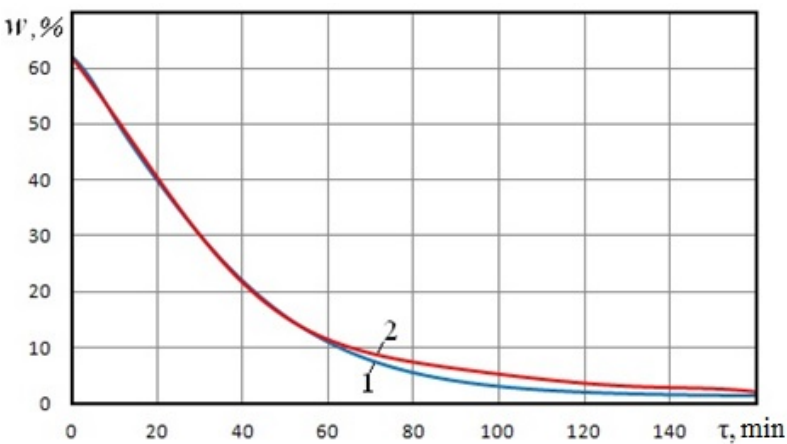

Figure 8. Dependence on time of relative concentration of moisture in a layer of soy in the course of its drying: 1 - results of numerical modeling; 2 - experimental data

From the analysis of numerical simulation data, as well as the results of comparing the calculated data with experimental data, we can conclude that the proposed numerical model satisfactorily describes the process of convection drying of crushed soybeans and can be used to calculate the mode parameters of this process. Comparing the results of the previously performed and presented in $[18 ; 19 ; 20]$ numerical modeling of convection drying of crushed beets with the results for crushed soybeans $[15 ; 20]$, we conclude that the proposed model satisfactorily describes the process of convection drying of colloidal capillary-porous materials.

\section{Conclusions}

The generalized analysis of the obtained data confirmed that the use of stepwise drying mode $100 / 60^{\circ} \mathrm{C}$ intensifies the drying process of phytoestrogenic mixtures (21\%), and also does not lead to deterioration of the quality characteristics of the final product.

Thus, the universality of this step mode makes it possible to reduce energy costs for convective drying and can be used in mass production of functional powders, which are an available source of natural vitamins and minerals to strengthen human immunity during epidemics and exacerbations of viral diseases.

Based on the results of derivatographic studies of antioxidant raw tissues (table beets, rhubarb and a mixture of table beets with rhubarb 2: 
1), it can be stated that the dehydration of the mixture occurs at a rate $10 \%$ higher than the average rate of dehydration of table beet tissues; the average specific heat of dehydration of the mixture is $13.5 \%$ lower than the heat of dehydration of table beets and almost $9 \%$ less than the heat of dehydration of rhubarb; the thermal stability of the mixture exceeds the thermal stability of table beets. Therefore, the developed beet-rhubarb composition for stabilization and protection of betanin from the effects of temperature during drying has in comparison with the components of the composition lower heat of dehydration and increased thermal stability.

According to derivatographic studies of phytoestrogenic raw materials based on soybeans, it was found that the average specific heat of dehydration of soybean-spinach mixture is $2.5 \%$ lower than the average specific heat of dehydration of spinach, but $1.6 \%$ higher than the average specific heat of dehydration of hydrothermally treated soybeans.

It is determined that the average rate of dehydration of the mixture is $10 \%$ higher than the average rate of dehydration of the components. Prolonged high-temperature exposure causes instant complete destruction of sugars, proteins and other nutrients components.

Therefore, taking into account the temperature ranges and physicochemical properties of the studied antioxidant and phytoestrogenic raw materials, long-term high temperature exposure is not recommended. The development of pre-treatment of antioxidant and phytoestrogenic mixtures allows to reduce energy consumption for the dehydration process and save the maximum amount of biologically active substances.

From the analysis of numerical simulation data, as well as the results of comparing the calculated data with experimental data, we can conclude that the proposed numerical model satisfactorily describes the process of convection drying of crushed soybeans and can be used to calculate the regime parameters of this process.

\section{References:}

1. Sz'ekely D., Ill'es B., Steger-Mate M., Monspart-S'enyi J. (2016). Effect of drying methods for inner parameters of red beetroot (Beta vulgaris L.). Acta Univ. Sapientiae, Alimentaria, 9: 60-68.

2. Jéssica Loraine Duenha, Rita de Cássia, Grasiele Scaramal (2018). Effect of $\mathrm{pH}$ on the stability of red beet extract (Beta vulgaris 1.) microcapsules produced by spray drying or freeze drying. Food Sci. Technol, Campinas, 38(1): 72-77. 
3. Kowalski Stefan J., Łechtańska Joanna M. (2015). Drying of red beetroot after osmotic pretreatment: Kinetics and quality considerations. Chemical and Process Engineering, 36(3): 345-354.

4. Mei Ling Ng, Rabiha Sulaiman (2018). Development of beetroot (Beta vulgaris) powder using foam mat drying. Food Science and Technology, 88: 80-86.

5. Park H.W., Han W.Y., Kang H.W. \& Yoon W.B. (2017). Drying characteristics of soybean (glycine max) using continuous drying and intermittent drying. Proceeding of the International Food Operations and Processing Simulation Workshop, 8-15.

6. Petrova Zh.O., \& Sniezhkin Yu.F. (2018). Enerhoefektyvni teplotekhnolohii pererobky funktsionalnoi syrovyny. Kyiv: Naukova dumka, $187 \mathrm{~s}$.

7. Petrova Zh.O., \& Slobodianiuk K.S. (2019). Energy-efficient modes of drying of colloidal capillary-porous materials. Journal of Engineering Physics and Thermophysics, vol. 92, no. 5, pp, 1231-1238.

8. Zh. Petrova, N. Dmytrenko, \& K. Slobodianiuk (2019). "Determination of heat of evaporation of soy-carrot mixture". 2nd International Scientific Conference «Chemical Technology and Engineering». Lviv, pp. 69-70.

9. V. I Formazyuk (2003) Enciklopediya pishchevyh lekarstvennyh rastenij: Kul'turnye i dikorastushchie rasteniya v prakticheskoj medicine. Kyiv: A.S.K..

10. Yu.F. Sniezhkin, Zh.O. Petrova, K.M. Samoilenko, \& V.A. Mykhailyk (2016). Deryvatohrafichne doslidzhennia znevodnennia betaninovmisnykh roslynnykh materialiv ta yikh termichnoi stiikosti. Naukovi pratsi ONAKhT, 1(80), pp. 27-31.

11. Petrova Zh.O., Paziuk V.M., Samoilenko K.M. \& Chepeliyk O.P. (2018). Effect of treatment modes on quality and antioxidant properties of tomato and beet processing products. Ukrainian food journal, vol. 7, issure 2, pp. 291-302.

12. Liniia dlia vyrobnytstva kompozytsiinykh antyoksydantnykh poroshkiv z roslynnoi syrovyny: pat. 109083 Ukraina: MPK A23V 7/02. № a 201404903 ; Zaiavl.08.05.2014, vydano 10.07.2015., biul. № 13.12. 135 .

13. Sposib oderzhannia fitoestrohennoho poroshku iz soi ta shpynatu: pat. 115741 Ukraina: MPK A23L 2/00, A23L 30/00, A23J 3/16. № a201613103; zaiavl. 22.12.16; opubl. 11.12.17, Biul. № 23.

14. Petrova Zh.O., \& Slobodianiuk K.S. (2019). Rozrobka enerhoefektyvnoho rezhymu sushinnia fitoestrohennoi roslynnoi syrovyny. Naukovi pratsi ONAKhT, $1(83)$, pp. 85-91.

15. Slobodianiuk K.S. (2020). Intensyfikatsiia protsesu sushinnia fitoestrohennoi syrovyny na osnovi soi: dys. kand. tekhn. nauk. Instytut tekhnichnoi teplofizyky NAN Ukrainy, Kyiv.

16. Sniezhkin Yu.F., Mykhailyk V.A. ta Dmytrenko N.V. (2011). "Dynamika zminy stanu vody v parenkhimnykh tkanynakh roslyn pry sushinni". Promyshlennaya teplotekhnika, t. 33, no. 2, pp. 35-40.

17. Mihajlik V.A., Dmitrenko N.V., Mihajlik T.A. (2007). Vliyanie termicheskogo vozdejstviya na sostoyanie vody v rastitel'nyh tkanyah. Promyshlennaya teplotekhnika, t. 29, no. 7, pp. 212-217. 
18. Petrova, Zh., Davydenko, B., Slobodianiuk K. (2019). Modeliuvannia teplomasoperenosu v protsesi sushinnia koloidnykh kapiliarno-porystykh materialiv. Keramika: Nauka i zhyttia, no. 2(43), pp. 7-14. https://doi.org/10.26909/ csl.2.2019.1

19. Samoilenko K.M. (2019). "Intensyfikatsiia teplomasoobminu pry kupazhuvanni ta sushinni antyoksydantnoi syrovyny": dys. kand. tekhn. nauk. Instytut tekhnichnoi teplofizyky NAN Ukrainy, Kyiv.

20. Petrova Zh.O., Slobodianiuk K.S. Chyselne modeliuvannia templomasoperenosu $\mathrm{v}$ koloidnykh kapiliarno-porystykh materialakh. Zbirnyk tez dopovidei XVI mizhnarodnoi naukovo-praktychnoi konferentsii studentiv, aspirantiv i molodykh vchenykh "Resursoenerhozberihaiuchi tekhnolohii ta obladnannia". Kyiv, 22-23 kvitnia 2019 r., pp. 19-20. 